\title{
Isolasi Bakteri Penghasil Indole Acetic Acid pada Tanaman Hortikultura di Perkebunan Prafi SP 1, Manokwari
}

\section{(Isolation of Bacteria Producing Indole Acetic Acid from the Horticulture Plant in Prafi SP 1 Plantation, Manokwari)}

\author{
Rina Anita Mogea*, Waode Intan Cendrasari La Halim Putri, Hermawaty Abubakar
}

(Diterima Desember 2020/Disetujui Desember 2021)

\begin{abstract}
ABSTRAK
Tanaman hortikultura merupakan cabang pertanian yang berhubungan dengan budi daya tanaman, seperti sayursayuran, buah, berbagai tanaman hias, dan tanaman obat-obatan yang membutuhkan senyawa untuk mempercepat pembentukan akar yang dapat dilakukan dengan menggunakan zat pengatur tumbuh (ZPT). Salah satu ZPT yang dibutuhkan untuk tanaman ialah auksin atau indole acetic acid (IAA). Adanya bakteri yang berperan sebagai penghasil IAA dapat digunakan untuk merangsang pertumbuhan tanaman hortikultura. Dengan demikian, penelitian ini merupakan eksplorasi bakteri yang berpotensi sebagai penghasil auksin yang selanjutnya dapat memberikan peranan yang besar dalam peningkatan produksi pertanian. Penelitian ini bertujuan untuk mengisolasi, menyeleksi, mengukur nilai IAA, dan mengkarakterisasi bakteri lokal penghasil IAA. Lokasi pengambilan sampel tanah rizosfer berasal dari perkebunan Prafi SP 1 Manokwari, Indonesia. Isolasi bakteri penghasil IAA dilakukan menggunakan media umum untuk pertumbuhan mikrooganisme, yaitu NA (Nutrien Agar) dan NB (Nutrien Broth). Hasil penelitian yang didapat menunjukkan bahwa sebanyak 9 isolat bakteri berasal dari rizosfer tanaman hortikultura. Setelah dilakukan seleksi isolat bakteri penghasil auksin didapat sebanyak 2 isolat bakteri positif yang mampu menghasilkan IAA, yaitu isolat IBPA 3 dan IBPA 5. Nilai konsentrasi IAA pada isolat IBPA 3 sebesar $42,178 \mathrm{ppm}$ dan pada isolat IBPA 5 sebesar 27,65 ppm. Karakteristik IBPA 3 mengarah ke genus Bacillus dan IBPA 5 mengarah ke genus Pseudomonas.
\end{abstract}

Kata kunci: bakteri rizosfer, indole acetic acid, pertanian

\section{ABSTRACT}

Horticultural plants are branches of agriculture that are associated with crop cultivation such as vegetables, fruit, various ornamental plants, and medicinal plants that require compounds to accelerate the formation of roots which can be done by using growth regulators. One of the growth regulators needed for plants is auxin or Indole Acetic Acid (IAA). The presence of bacteria that act as producers of IAA can be used to stimulate the growth of horticultural plants. Therefore, the exploration of bacteria that have the potential to produce auxin in the future can provide an important and significant role in increasing agricultural production. This study aims to isolate, select, measure the value of IAA, and characterize IAA-producing bacteria. Isolation of auxin-producing bacteria using general media of growth bacteria, i.e., Nutrient Agar (NA) and Nutrient Broth (NB). The location for sampling of rhizosphere soil was Prafi SP 1 Plantation, Manokwari, Indonesia. The results showed that as many as 9 bacterial isolates were obtained from the rhizosphere of horticultural plants. After selection of auxin-producing bacteria, 2 bacteria isolates (IBPA 3 and IBPA 5) were obtained which were able to produce IAA. IAA concentration value in IBPA 3 isolate is $42.178 \mathrm{ppm}$ and in IBPA 5 isolate is $27.65 \mathrm{ppm}$. The characteristics of IBPA 3 isolate refer to the genus Bacillus and IBPA 5 isolate refer to the genus Pseudomonas.

Keywords: agriculture, bacteria rhizosphere, indole acetic acid

\section{PENDAHULUAN}

Tanaman hortikultura adalah tanaman pertanian yang berhubungan dengan budi daya, seperti sayursayuran, buah, berbagai tanaman hias, dan tanaman obat-obatan. Tanaman hortikultura menjadi komoditas unggulan untuk pertumbuhan ekonomi sehingga pendapatan masyarakat juga meningkat (Pusitasari 2017). Salah satu cara untuk meningkatkan produksi tanaman

Jurusan Biologi, Fakultas Matematika dan Ilmu Pengetahuan Alam, Universitas Papua, Jl. Gunung Salju Amban, Manokwari, Papua Barat 98314

* Penulis Korespondensi: Email: rinamogea@gmail.com hortikultura ini adalah menyediakan lahan yang subur. Kesuburan lahan dapat diusahakan dengan memberikan pupuk hayati. Bakteri dapat berperan sebagai sumber pupuk hayati dan salah satunya sebagai sumber auksin yang dapat digunakan untuk merangsang pertumbuhan tanaman hortikultura. Sifat bakteri yang dapat dikultur dan waktu inkubasi yang cepat akan memudahkan untuk menghasilkan auksin dalam waktu yang tidak lama. Auksin adalah salah satu zat pengatur tumbuh akar tanaman sehingga dapat meningkatkan proses penyerapan unsur hara ke dalam sel tanaman (Alpriani \& Anna 2018).

Zat pengatur tumbuh (ZPT) atau hormon pada tanaman adalah bahan organik yang tidak dikelom- 
pokkan sebagai nutrisi, dan bahan ini dalam konsentrasi rendah dapat mendorong, menghambat, atau mengubah pertumbuhan dan perkembangan tanaman (Viza \& Arista 2018). Salah satu dari zat pengatur tumbuh yang dibutuhkan oleh tanaman adalah auksin. Ada beragam jenis auksin dan jenis auksin yang umum digunakan adalah Napthalene Acetic Acid (NAA), Indole Acetic Acid (IAA), dan Indole Butyric Acid (IBA). Pemanfaatan auksin berperan dalam berbagai aspek pertumbuhan dan perkembangan tanaman (Prastyo 2016).

Hormon IAA merupakan fitohormon auksin yang memiliki IAA eksogen dan endogen. IAA eksogen merupakan hormon yang dihasilkan oleh sel di luar sel tumbuhan, yaitu oleh bakteri, seperti Agrobacterium tumefaciens, Pseudomonas sp., dan Azotobacter sp. Sementara itu, IAA endogen merupakan hormon yang dihasilkan oleh sel-sel tanaman itu sendiri. Kandungan bahan IAA rendah pada tanaman dapat menstimulasi pemanjangan akar utama, sedangkan bila kandungan bahan IAA tinggi dapat menstimulasi pembentukan akar lateral dan akar adventif (Astriani 2015).

Penelitian ini dilakukan dengan tujuan untuk mengisolasi, menyeleksi, mengukur nilai IAA, dan mengkarakterisasi bakteri lokal penghasil IAA. Manfaat penelitian ini diharapkan akan memberikan informasi tentang bakteri lokal penghasil IAA yang berperan penting dalam meningkatkan pertumbuhan tanaman.

\section{METODE PENELITIAN}

\section{Pengambilan Sampel Tanah}

Sampel tanah yang dipakai pada penelitian ini adalah tanah rizosfer yang berasal dari perkebunan Prafi SP 1 Manokwari yang ditanami sayur-sayuran berupa bayam, kangkung, dan terong. Sampel tanah diambil pada kedalaman $\pm 5-10 \mathrm{~cm}$ di sekitar perakaran tanaman sayur yang diambil dari beberapa titik dan kemudian dikomposit (Fallo 2015). Sampel tanah dimasukkan ke dalam kantong untuk dilakukan pengujian di Laboratorium Mikrobiologi FMIPA, Unipa. Pengambilan sampel dilakukan pada 17 Maret 2019.

\section{Isolasi Bakteri Rizosfer}

Dalam memperoleh isolat bakteri rizosfer dilakukan sebagai berikut, yaitu sampel tanah ditimbang sebanyak $12,5 \mathrm{~g}$ dan dimasukkan ke dalam larutan fisiologis $112,5 \mathrm{~mL}$, lalu diaduk hingga homogen dan diencerkan secara berseri, yaitu pengenceran berseri kelipatan 10 sampai tingkat pengenceran $10^{-5}$. Selanjutnya, hasil pengenceran $10^{-5}, 10^{-6}$, dan $10^{-7}$ diambil masing-masing sebanyak $0,1 \mathrm{~mL}$ dan disebar menggunakan batang spreader pada setiap cawan petri yang telah berisi media NA dan kemudian diinkubasi pada suhu ruang selama 48 jam.

\section{Pemurnian Isolat Bakteri Rizosfer}

Bakteri yang tumbuh pada media NA terlihat beragam kemudian bakteri dipindahkan ke media NA dan selanjutnya dimurnikan dengan cara mengamati koloni yang tumbuh pada media NA. Selanjutnya, bila terdapat koloni bakteri yang belum terpisah maka dapat dilakukan pemurnian dalam cawan petri yang berisi NA, dengan cara menggunakan metode kuadran. Lalu koloni diinkubasi pada suhu ruang selama 48 jam. Setelah mendapatkan hasil dari metode kuadran, dilakukan karakterisasi jenis bakteri secara deskriptif dengan melihat ciri makroskopis yang meliputi elevasi, margin, shape, dan warna koloni tunggal bakteri. Kemudian koloni yang tumbuh dapat diambil menggunakan ose lalu digores pada media NA miring dengan pola zig zag. Dengan demikian, diperoleh isolat murni. Kemudian isolat diinkubasi pada suhu ruang selama 48 jam.

\section{Seleksi Isolat Bakteri Penghasil Auksin}

Prosedur seleksi isolat bakteri penghasil auksin adalah menggunakan media NB yang ditambahkan dengan L-triptofan sebanyak $0,1 \mathrm{~g}$. Isolat murni dimasukkan ke dalam erlenmeyer yang berisi media NB cair. Kemudian erlenmeyer diinkubasi pada shaker dengan kecepatan $100 \mathrm{rpm}$ selama enam hari pada suhu ruang hingga isolat bakteri tumbuh pada media. Warna isolat bakteri yang tumbuh akan menjadi keruh dan diambil sebanyak $5 \mathrm{~mL}$ dengan mikropipet dan dipindahkan ke dalam microtube dan disentrifius selama 30 menit dengan kecepatan 7000 rpm. Selanjutnya diambil satu $\mathrm{mL}$ supernatan dan dibubuhkan dengan $4 \mathrm{~mL}$ reagen Salkowski. Supernatan diinkubasi selama waktu 24 jam dan diamati perubahan warna yang terjadi. Bila terjadi perubahan warna dan warna isolat sampel berubah menjadi merah muda maka hal ini mengindikasikan bahwa isolat bisa menghasilkan IAA (Pattern \& Glick 2002).

\section{Analisis Bakteri Penghasil Auksin}

Analisis hormon auksin dilakukan dengan tahapan berikut. Sebanyak $25 \mathrm{~mL}$ larutan media NB ditambahkan isolat bakteri yang dapat menghasilkan IAA, kemudian diinkubasi pada shake incubator pada suhu $30^{\circ} \mathrm{C}$ dengan agitasi $100 \mathrm{rpm}$ dan diukur densitas optiknya pada $0,24,48$, dan 72 jam. Lalu media NB yang telah diinokulasi dengan isolat diambil sebanyak $2 \mathrm{~mL}$ kemudian disentrifius dengan kecepatan 10.000 rpm selama 10 menit (Sukmadewi et al. 2015). Selanjutnya dilakukan pengukuran absorbansi dengan menggunakan alat spektrofotometer pada panjang gelombang sekitar $535 \mathrm{~nm}$. Kandungan hormon IAA dihitung setelah dibandingkan dengan kurva larutan standar IAA.

\section{Pembuatan Kurva Standar IAA dan Pengukuran IAA}

Pembuatan kurva standar IAA dilakukan dengan menggunakan sebanyak $2,5 \mathrm{mg}$ IAA sintetik yang dilarutkan ke dalam $50 \mathrm{~mL}$ metanol. Kemudian, larutan IAA sintetik dimasukkan ke dalam tabung reaksi dengan menggunakan mikropipet masing-masing 20 $\mu \mathrm{l}, 100 \mu \mathrm{l}, 200 \mu \mathrm{l}, 300 \mu \mathrm{l}, 400 \mu \mathrm{l}$, dan $900 \mu \mathrm{l}$. Lalu 
dibubuhkan larutan metanol sampai volume masingmasing tabung reaksi tersebut menjadi $1000 \mu \mathrm{l}$, kemudian dibubuhkan sebanyak empat $\mathrm{ml}$ reagen Salkowski pada setiap tabung reaksi, lalu dihomogenkan dan diinkubasi selama 60 menit pada suhu ruang (Pattern \& Glick 2002). Setelah itu, dilakukan pengukuran absorbansi larutan standar dengan menggunakan spektrofotometer pada panjang gelombang $520 \mathrm{~nm}$. Selanjutnya dilakukan pembuatan kurva larutan standar IAA menggunakan hasil spektrofotometer yang dinyatakan dengan hubungan antara larutan standar IAA (x) dan absorbansinya $(\mathrm{y})$.

\section{Uji Fisiologis dan Pewarnaan}

Uji fisiologis pada penelitian ini meliputi uji indol, motil, urea, TSIA, dan gelatin, di samping itu dilakukan juga pewarnaan Gram dan spora (Cappucino \& Sherman 2014). Data yang diamati meliputi morfologi koloni, bentuk sel, perubahan warna pada media tanam, pergerakan sel, dan penentuan nilai IAA.

\section{HASIL DAN PEMBAHASAN}

Sampel tanah rizosfer yang telah ditentukan titik pengambilannya, diambil menggunakan bor tanah dengan kedalaman 5-10 cm. Hal ini dilakukan karena pada kedalaman tanah yang diambil sudah memasuki zona perakaran rizosfer. Pengambilan sampel dilakukan sebanyak tiga titik kemudian dikomposit untuk memperbesar peluang mendapatkan isolat bakteri yang banyak dan mampu menghasilkan IAA. Hewindati et al. (2006) menyatakan bahwa tanah berpasir mempunyai kemampuan yang lebih sedikit untuk menyimpan air dibanding debu dan tanah liat. Akan tetapi, tanah yang diperlukan untuk tanaman hortikultura terdiri atas campuran ketiga pertikel tersebut yang dinamakan struktur tanah. Kemampuan menahan air lebih besar terjadi pada struktur tanah yang mempunyai partikel kecil. Kemampuan menahan air akan lebih tinggi jika di dalam tanah terdapat kandungan kompos organik.

Isolat bakteri dari tanaman hortikultura yang diisolasi dengan media NA diperoleh sebanyak dua isolat bakteri yang memiliki potensi penghasil IAA. Isolat murni dapat dibedakan berdasarkan elevasi, margin, shape, dan warna koloni tunggal bakteri menurut Cappuccino \& Sherman (2014) yang disajikan pada Tabel 1.

Berdasarkan hasil penelitian diperoleh dua isolat bakteri pada rizosfer tanaman hortikultura yang memiliki karakteristik morfologi yang berbeda. Pada penelitian Fallo (2015) yang mengeksplorasi bakteri

Tabel 1 Morfologi isolat bakteri rizosfer

\begin{tabular}{cllll}
\hline \multirow{2}{*}{ Isolat } & \multicolumn{4}{c}{ Morfologi koloni } \\
\cline { 2 - 5 } & Warna & Elevasi & Margin & Shape \\
\hline IBPA 3 & Putih & Flat & Undulate & Irreguler \\
IBPA 5 & Kuning & Convex & Entire & Circular \\
\hline
\end{tabular}

penghasil auksin dari lahan sawah memperoleh 8 isolat. Akan tetapi, dari hasil penelitian Firdausi (2018) yang mengeksplorasi bakteri rizosfer penghasil IAA dari tegakan Hutan Raya Suren memperoleh 21 isolat. Dari hasil penelitian yang dilakukan terlihat ada perbedaan dalam jumlah isolat bakteri yang ditemukan pada lahan sawah, hutan rakyat, dan juga areal perkebunan. Hal ini diduga karena ada perbedaan lingkungan rizosfer yang juga ada perbedaan kelembapan tanah ataupun jenis tanah yang berbeda di sekitar perakaran rizosfer serta penggunaan media yang berbeda dalam proses isolasi bakteri. Menurut Firdausi (2018), terdapat peluang yang lebih besar untuk memperoleh jumlah isolat yang lebih banyak dengan menggunakan media yang spesifik. Banyak sedikitnya jumlah isolat bakteri pada setiap rizosfer dalam suatu perkebunan seharusnya dipengaruhi oleh senyawa organik (eksudat) yang ada pada akar suatu tanaman. Eksudat akar adalah hal penentu keanekaragaman dan jumlah populasi mikroorganisme yang berada pada perakaran tanaman (Patil 2011).

Bakteri penghasil IAA dapat diamati melalui perubahan warna isolat yang telah ditambahkan reagen Salkowski untuk mendeteksi isolat bakteri yang mampu menghasilkan IAA. Dari hasil penelitian ini, perubahan warna yang diamati pada setiap isolat setelah satu hari diinkubasi di ruangan gelap, diperoleh sebanyak dua isolat bakteri yang menghasilkan warna merah muda dan selanjutnya kedua isolat ini dipakai untuk mengukur kandungan IAAnya. Dari hasil pengukuran spektrofotometri selanjutnya dibuat kurva larutan standar IAA yang memperlihatkan hubungan antara larutan standar IAA dengan notasi $(x)$ dan absorbansi notasinya (y), sehingga dalam perhitungan akan diperoleh persamaan regresi, yaitu $R^{2}=0,939$ dan $y=0,014 x+0,012$. Hasil persamaan ini dipakai untuk menghitung kandungan IAA isolat bakteri seperti yang disajikan pada Gambar 1. Dalam menghitung kandungan atau konsentrasi IAA dalam supernatan, isolat bakteri hasil penelitian dikerjakan melalui perhitungan, yaitu mengubah notasi y pada persamaan kurva standar dengan hasil pengukuran absorbansi supernatan isolat bakteri yang tertinggi dari kedua sampel isolat. Dari hasil pengukuran kurva standar IAA diperoleh nilai $x$ yang dipakai sebagai nilai konsentrasi IAA supernatan isolat bakteri pada Gambar 2. Menurut Firdausi (2018), nilai konsentrasi IAA yang didapat ditulis dalam satuan ppm. Berdasarkan uji kuantitatif menunjukkan bahwa isolat IBPA 3 dan IBPA 5 menghasilkan IAA tertinggi pada waktu inkubasi 42 jam dan memiliki nilai konsentrasi IAA yang berbeda yang dapat dilihat pada Gambar 1. IBPA 3 memiliki nilai konsentrasi IAA sebesar 42,178 ppm, sedangkan IBPA 5 memiliki nilai konsentrasi IAA sebesar $27,65 \mathrm{ppm}$.

Uji fisiologis digunakan untuk melihat sifat biokimia bahan yang dihasilkan oleh isolat bakteri. Uji fisiologis yang dilakukan di antaranya adalah uji indol, uji motil, uji urea, uji TSIA, dan uji gelatin yang hasilnya disajikan pada Tabel 2. Hasil uji indol diketahui bahwa kedua isolat bakteri tersebut adalah negatif atau tidak 


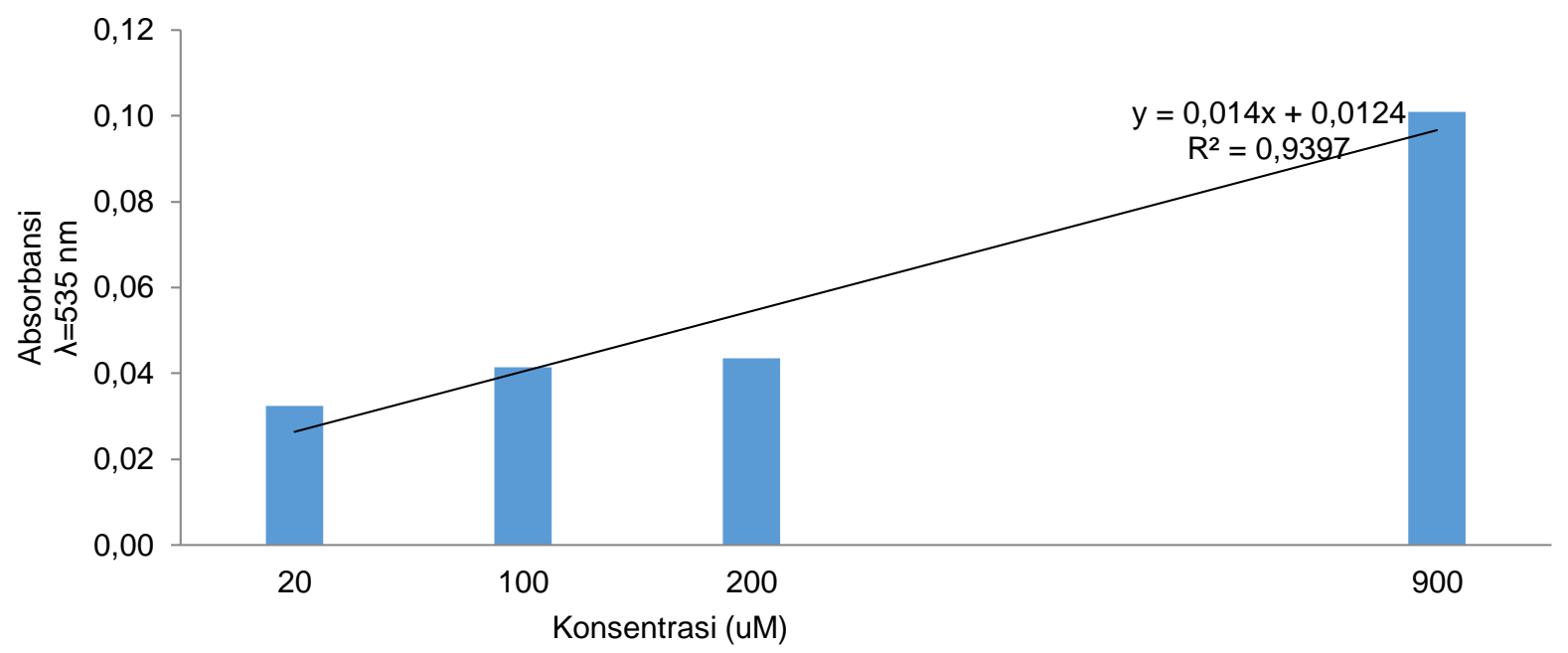

Gambar 1 Kurva standar indole acetic acid (IAA).

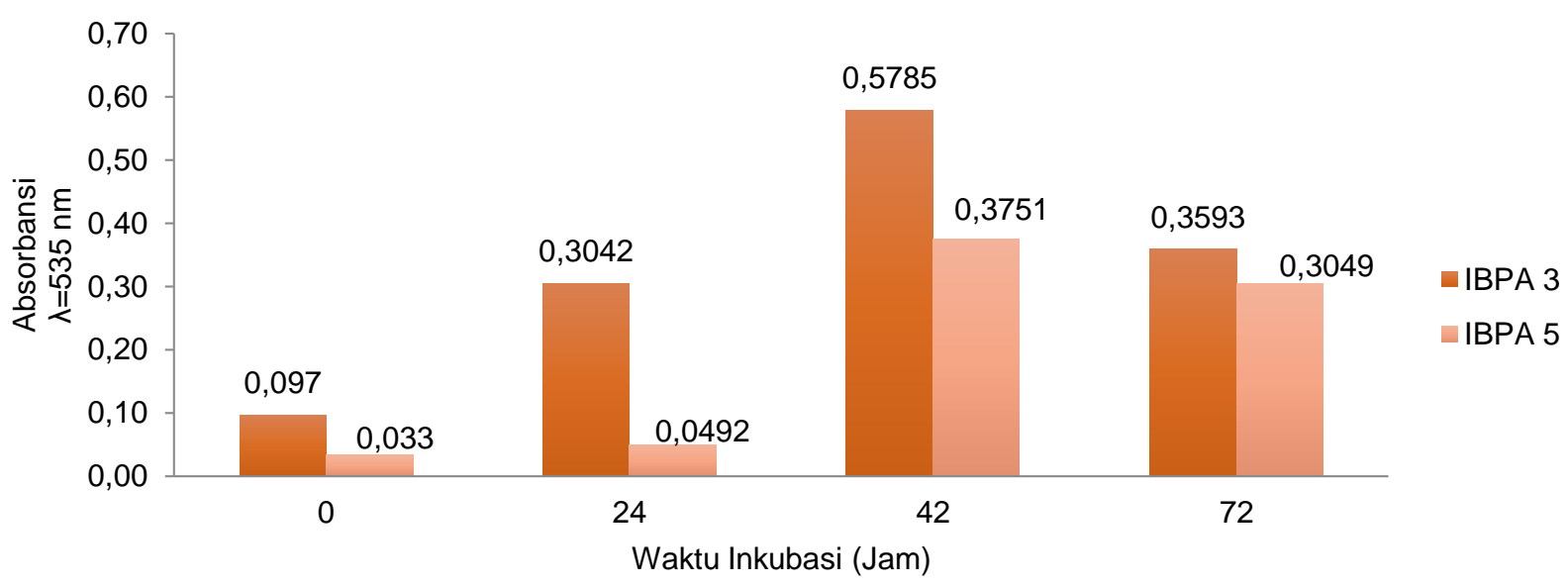

Gambar 2 Pengukuran absorbansi bakteri penghasil indole acetic acid (IAA).

Tabel 2 Karakteristik fisiologi dan motilitas isolat bakteri penghasil IAA hasil isolasi dari tanah pertanian Prafi, Manokwari

\begin{tabular}{|c|c|c|c|c|c|c|c|c|c|c|}
\hline \multirow{2}{*}{ Isolat } & \multirow{2}{*}{ Indol } & \multirow{2}{*}{ Motil } & \multirow{2}{*}{ Urea } & \multicolumn{6}{|c|}{ TSIA } & \multirow{2}{*}{ Gelatin } \\
\hline & & & & Dex & Lak & Suk & Gas & $\mathrm{H}_{2} \mathrm{~S}$ & $\mathrm{Al} / \mathrm{Ac}$ & \\
\hline IBPA 3 & - & - & - & + & - & - & - & - & $A c$ & + \\
\hline IBPA 5 & - & - & - & + & - & - & - & - & Ac & + \\
\hline
\end{tabular}

menghasilkan indol yang ditandai dengan tidak memunculkan cincin merah pada permukaan media. Pada uji motil diketahui bahwa kedua isolat bakteri negatif atau tidak melakukan pergerakan yang ditandai dengan tidak memunculkan penyebaran pertumbuhan bakteri sepanjang permukaan tusukan pada media SIM. Hasil uji urea diketahui bahwa kedua isolat bakteri tidak menghasilkan urease. Hasil uji TSIA diketahui bahwa kedua isolat bakteri dapat memfermentasi dekstrosa. Hasil uji gelatin diketahui bahwa kedua isolat bakteri dapat memecah ikatan gelatin.

Hasil pewarnaan Gram yang dilakukan pada kedua isolat bakteri menunjukkan bahwa kedua isolat bakteri memiliki morfologi sel yang berbeda. IBPA 3 memiliki morfologi sel berupa batang (bacil), yang bersifat Gram positif yang ditunjukkan dengan warna ungu. IBPA 5 memiliki morfologi sel berupa bacil, yang bersifat Gram negatif yang ditunjukkan dengan warna merah muda yang dapat dilihat pada Gambar 2. Pewarnaan spora dilakukan untuk melihat adanya endospora pada bakteri yang memiliki morfologi bacil dan bersifat Gram positif. Hasil pewarnaan spora yang dilakukan pada IBPA 3 memiliki endospora yang dapat dilihat pada Gambar 3.

Berdasarkan hasil uji fisiologis, pewarnaan Gram dan pewarnaan spora yang telah dilakukan menurut buku Identifikasi Bergey's Manual of Determinative Bakteriology Ninth Edition (Holt et al. 1994) menunjukkan bahwa isolat IBPA 3 mengarah ke genus Bacillus dan isolat IBPA 5 mengarah ke genus 

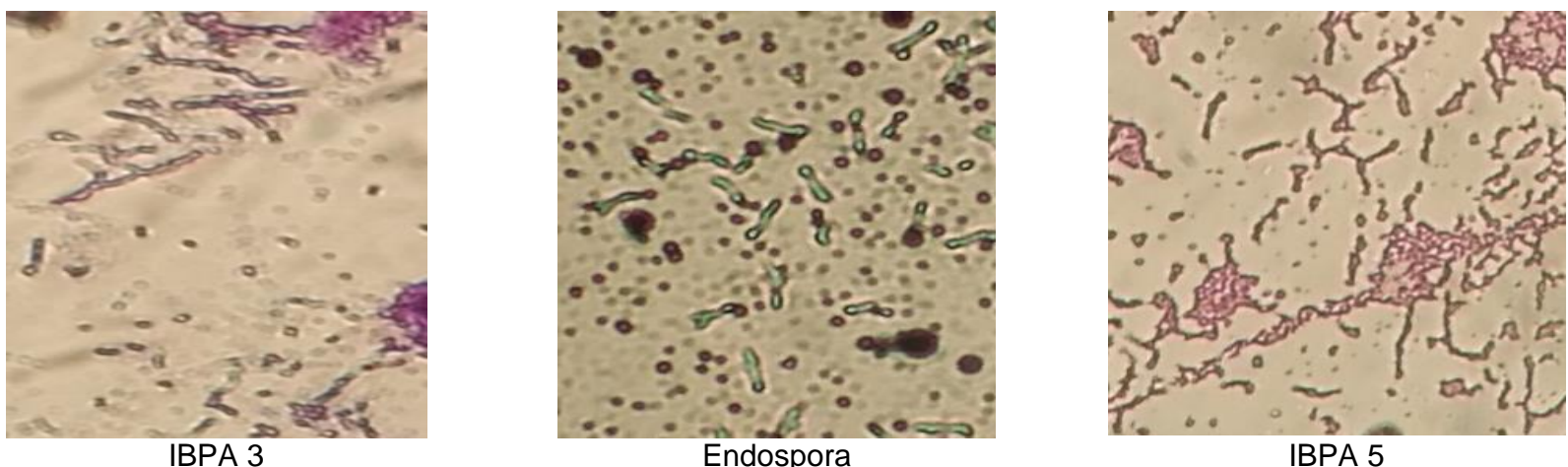

Gambar 3 Bentuk sel isolat penghasil IAA berbentuk batang dan Endospora isolat IBPA 3 terletak di ujung sel (terminal) dengan tanda anak panah

Pseudomonas. Berdasarkan buku identifikasi, beberapa uji fisiologi dan pewarnaan pada isolat IBPA 3 dari bakteri genus Bacillus merupakan bakteri Gram positif dengan berbentuk batang (baci), memiliki endospora, tidak motil, dan bersifat asam (acid) yang dapat memfermentasi dekstrosa, sementara pada isolat IBPA 5 dari bakteri genus Pseudomonas merupakan bakteri dengan koloni berwarna kuning, Gram negatif dengan bentuk batang (bacil), dan tidak memiliki cincin merah.

Bakteri genus Bacillus dan Pseudomonas merupakan bakteri yang dapat menghasilkan IAA. Menurut Widayanti (2007) dalam penelitiannya diper-oleh bakteri Bacilus sp. yang mempunyai konsentrasi IAA, yaitu sampai 67,2 ppm ketika ditambahkan dengan triptofan $0,5 \mathrm{~g}$, sedangkan kalau tanpa penambahan triptofan hanya diperoleh kandungan IAA sebanyak 38,9 ppm. Penelitian Patten \& Glick (2002) menemukan bahwa bakteri Pseudomonas putida yang dibubuhkan dengan triptofan sebayak 0,5 g menghasilkan IAA sebesar 68,3 ppm. Pada penelitian ini, genus Bacillus yang diperoleh menghasilkan hormon IAA sebesar 42,178 ppm dan Pseudomonas menghasilkan hormone IAA sebesar 27,65 ppm dengan penambahan triptofan sebanyak $0,1 \mathrm{~g}$. Berdasarkan tingkat produksi hormon IAA pada kedua bakteri ini dapat disimpulkan bahwa kedua bakteri ini dapat digunakan sebagai pupuk hayati. Menurut Patten dan Glick (2002), hormon IAA yang dihasilkan oleh bakteri bisa meningkatkan pertumbuhan tanaman melalui pemacuan proses diferensiasi akar pada saat membuat rambut akar. Apabila kandungan atau konsentrasi IAA rendah maka hormon ini hanya bisa merangsang pemanjangan akar utama dan bila kandungan atau konsentrasi IAA tinggi sebaliknya maka hormon ini bisa merangasang pembentukan akar lateral dan juga akar adventif. Pertumbuhan akar, baik akar lateral dan akar adventif, sangat penting bagi tanaman yang masih muda untuk membantu penyerapan unsur hara.

\section{KESIMPULAN}

Berdasarkan hasil penelitian diperoleh dua isolat bakteri lokal yang memiliki kemampuan untuk menghasilkan senyawa Indole Acetic Acid (IAA) asal rizosfer tanaman hortikultura dari Prafi Manokwari. Isolat IBPA 3 memiliki nilai konsentrasi IAA 42,178 ppm, sedangkan IBPA 5 memiliki nilai konsentrasi IAA 27,65 ppm. Karakteristik IBPA 3 meliputi pewarnaan Gram, pewarnaan spora, uji motil, dan uji TSIA mengarah ke genus Bacillus. Karakteristik IBPA 5 meliputi morfologi koloni, pewarnaan Gram, dan uji indol mengarah ke genus Pseudomonas.

\section{DAFTAR PUSTAKA}

Alpriyan D, Karyawati AS. 2018. Pengaruh Konsentrasi dan Lama Perendaman Hormon Auksin Pada Bibit Tebu (Saccharum officinarum L.) Teknik Bud Chip. Jurnal Produksi Tanaman. 6(7): 1354-1362.

Astriani M. 2015. Seleksi Bakteri Penghasil Indole Acetic Acid (IAA) dan Pengujian Pada Bibit Kelapa Sawit (Elais guneensus Jacq.). [Tesis]. Bogor (ID): Institut Pertanian Bogor.

Cappucino JG, Sherman N. 2014. Microbiology: A Laboratory Manual. USA (US): Pearson Education,Inc

Fallo G. 2015. Isolasi Bakteri Penghasil Auksin Dan Pelarut Fosfat Dari Lahan Sawah Dan Aplikasinya Di Kabupaten Timor Tengah Utara. [Tesis]. Bogor (ID): Institut Pertanian Bogor.

Firdausi A. 2018. Isolasi Bakteri Rhizosfer Penghasil IAA (Indole Acetic Acid) Dari Tegakan Hutan Rakyat Suren. [Skripsi]. Makassar (ID): Universitas Hasanuddin.

Hewindati YT, Sulistiana S, Nurmawati S, Winarti I, Puspitasari KA, Pratomo H, Elisabet NK, Waskito A, Nadia L. 2008. Hortikultura. Universitas Terbuka Press.

Holt GJ, Krieg RN, Sneath AHP, Staley TJ, Williams TS. 1994. Bergey's Manual of Determinative Bacteriology Ninth Edition. Lippincott Williams and Wilkins. A Wolters Kluwer Company. 
Patil V. 2011. Production of Indole Acetic Acid by Azotobacter sp. Recent Research Science and Technology. 3(12): 14-16.

Pattern CL, Glick BR. 2002. Role of Pseudomonas putida Indoleacetic Acid in Development of the Host Plant Root System. Applied and Environmental Microbioogyl. 68(8): 3795-3801. https://doi.org/ 10.1128/AEM.68.8.3795-3801.2002

Prastyo KA. 2016. Efektivitas Beberapa Auksin (NAA, IAA dan IBA) Terhadap Pertumbuhan Tanaman Zaitun (Olea europaea L.) Melalui Teknik Stek Mikro. [Skirpsi]. Malang (ID): Universitas Islam Negeri.

Pusitasari VD. 2017. Analisis Pengaruh Faktor-Faktor Produksi Terhadap Produksi Jamur Tiram dan Efisiensi Ekonomi di Desa Genting Kecamatan Jambu Kabupaten Semarang. [Skripsi]. Semarang
(ID): Universitas Diponegoro. https://doi.org/ 10.14710/agrisocionomics.v1i1.1645

Sukmadewi DKT, Suharjono, Antonius S. 2015. Uji Potensi Bakteri Penghasil Hormon IAA (Indole Acetic Acid) dari Tanah Rhizosfer Cengkeh (Syzigium aromaticum L.). Jurnal Biotropika. 3(2): 91-94.

Viza RY, Ratih A. 2018. Pengaruh Komposisi Media Tanam dan ZPT Air Kelapa terhadap Pertumbuhan setek pucuk Jeruk Kacang (Citrus reticulata Blanco). Jurnal Biologi Universitas Andalas. 6(2): 2303-216. https://doi.org/10.25077/jbioua.6.2.98106.2018

Widayanti T. 2007. Isolasi Dan Karakterisasi Bacillus sp. Indigenus Penghasil Asam Indol Asetat Asal Tanah Rizosfer. [Skripsi]. Bogor (ID): Institut Pertanian Bogor 